\title{
イチゴハナゾウムシの通過を阻害できる防虫ネットの 目合いについて
}

\author{
井 村 岳 男 \\ （奈良県農業総合センター）
}

2006年の春に，奈良県内の促成イチゴ栽培施設で，イ チゴハナゾウムシ Anthonomus bisignifer Schenkling の加 害による蕾の激しい被害が発生した。その後, 発生地点 は拡大しており, 早急な防除方法の確立が求められて いる。

本種は年 1 回発生で, 4 〜 月に発生する越冬成虫が イチゴの蕾を加害して萎れさせるほか，第 1 世代成虫が 果実や花弁，育苗株の新葉を食害する。戦前には主に関 東以北の露地栽培で重要害虫であったが, 戦後は促成栽 培の普及によって, 本圃での被害はほとんど発生しなく なった（小林，1986）。そのため, 本種のイチゴにおけ る発生生態と防除に関する研究例は，1950年代以前の北 海道における断片的な報告（木下と新開, 1926 ; 遠藤, 1927 ; 遠藤, 1952）があるのみである。作物病害虫ハン ドブックには，マラソン, DDVP などの有機リン剂が本 種の防除に有効との記述がある（小林，1986）が，研究 データは公表されていない。また，有機リン剤はイチゴ における收穫前使用日数が 3 日以上ある上に, 受粉用ミ ツバチに対する影響が強い。イチゴの促成施設栽培では, 本種の発生時期である 4 ～月にはほぼ毎日収穫を行っ ており，受粉用ミツバチも導入していることから，この 時期の有機リン剂の使用は困難である。また，奈良県で 現在被害が発生している圃場の多くは観光農園であるこ とから，収穫期の殺虫剤使用をできるだけ控えたいとす る園主も多い。そこで，施設開口部への防虫ネット被覆 による防除技術確立のため, 本種成虫の通過を阻害でき る防虫ネットの目合いを調査した。

\section{調査方法}

2007年 4 月19日から 5 月 24 日の間に奈良県高市郡明日 香村の促成イチゴ栽培施設で，イチゴハナゾウムシの卵 もしくは幼虫, 蛹が寄生する被害蕾を随時採集した。こ れを $25^{\circ} \mathrm{C}$ 全明条件下で飼育した後，羽化した第 1 世代 成虫を飼育ケージに移し，慨としてイチゴ未成熟果実と
ノイバラの新梢を与えて，室温条件下で維持したものを 試験に供試した。

内径 $2.7 \mathrm{~cm} \times$ 高さ $10 \mathrm{~cm}$ のプラスチック製管瓶に成虫 10頭を投入し, 開口部を防虫ネットで覆って, 輪ゴムで 止めた(第 1 困)。防虫ネットには, “サンサンネット”（日 本ワイドクロス株式会社, ポリエチレン製, 透明）と“ク レモナ寒冷紗 ${ }^{\circledR}$ （株式会社クラレ，ビニロン製，白色） を使用し，それぞれ第 1 表に示した目合いのネットを供 試した。次に開口部を上にして, $25^{\circ} \mathrm{C}$ 全明条件下に 30 分置いた後, 管瓶内に残存する成虫数を計数した。試験 は 5 反復で行い, 残存虫数の合計值を供試虫数の合計值 で除して, ネットの通過阻害率を算出した。なお, 対照 区はネットを被覆しない管瓶とした。

\section{結果および考察}

第 1 表に供試した防虫ネットの通過阻害率を示した。 供試成虫は管瓶内に投入後, 直ちに上方へ向かって, 壁 面をよじ登るか飛翔する行動が観察され，対照区では30 分後には全ての成虫が管瓶を脱出していた。“サンサン ネット ${ }^{\circledR}$ の $1 \times 1 \mathrm{~mm}$ と $0.8 \times 0.8 \mathrm{~mm}$ 目合いの処理区は

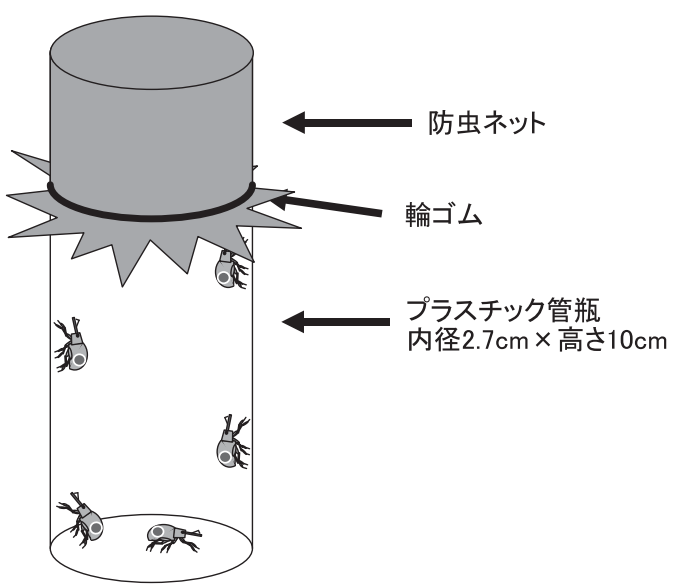

第 1 図 実験装置 
第 1 表 防虫ネットの目合いがイチゴハナゾウムシ成虫の通過阻害率におよばす影響

\begin{tabular}{lcccc}
\hline 商品名 & 目合い $(\mathrm{mm})$ & 供試虫数 & 残存虫数 & 通過阻害率 $(\%)$ \\
\hline サンサンネット & & & & \\
GN-2300 & $0.8 \times 0.8$ & 50 & 50 & 100 \\
U-2000 & $1 \times 1$ & 50 & 50 & 100 \\
N-7000 & $2 \times 2$ & 50 & 2 & 4 \\
クレモナ寒冷紗 & & & & \\
$\# 100$ & $1.4 \times 1.4$ & 50 & 50 & 100 \\
$\# 150$ & $1.68 \times 1.68$ & 50 & 24 & 48 \\
$\# 200$ & $2.1 \times 2.1$ & 50 & 3 & 0 \\
ネットなし & - & 50 & 0 & 0 \\
\hline
\end{tabular}

いずれも，成虫は全く通過しなかったが，2×2 mm で はほとんどの成虫が通過した。また, ‘クレモナ寒冷紗伖” の $1.4 \times 1.4 \mathrm{~mm}$ 目合いでは，成虫は全く通過しなかった が, $1.68 \times 1.68 \mathrm{~mm}$ では半数以上がネットを通過し， 2.1 $\times 2.1 \mathrm{~mm}$ ではほとんどの成虫が通過した。

以上の結果から, ‘サンサンネット®' では $1 \times 1 \mathrm{~mm}$ 以下の目合いで, ‘クレモナ寒冷紗の では $1.4 \times 1.4 \mathrm{~mm}$ の目合いでイチゴハナゾウムシ成虫の侵入を遮断できる と考えられた。今後はこれらのネットを被害発生戋場に
設置して防除効果を実証する必要があると考えられる。

\section{引用文献}

1）遠藤和衛（1927）北農 $1: 119-122$.

2）遠藤和衛（1952）北農 $19: 420-425$.

3）木下周太・新開 悟（1926）農及び園 1:3-12.

4）小林義明（1986）（1）イチゴハナゾウムシ。作物病害虫ハ ンドブック（梶原敏宏・梅谷献二・浅川 勝編）。養賢堂, 東京, p. 1012 